\title{
How phloem-feeding insects face the challenge of phloem-located defenses
}

\author{
Torsten Will ${ }^{1}{ }^{\dagger}$, , Alexandra C. U. Furch ${ }^{1 \dagger}$ and Matthias R. Zimmermann ${ }^{2}$ \\ 1 Institute of Phytopathology and Applied Zoology, Centre for BioSystems, Land Use and Nutrition, Justus-Liebig-University, Giessen, Germany \\ 2 Institute of General Botany, Justus-Liebig-University, Giessen, Germany
}

\section{Edited by:}

Gary A. Thompson, Pennsylvania

State University, USA

Reviewed by:

Sylvie Dinant, Institut National

de la Recherche Agronomique, France

Jyoti Shah, University of North Texas,

USA

Tom Wilkinson, University College

Dublin, Ireland

\section{${ }^{*}$ Correspondence:}

Torsten Will, Institute of

Phytopathology and Applied Zoology,

Centre for BioSystems, Land Use and

Nutrition, Justus-Liebig-University,

Heinrich-Buff-Ring 26-32, D-35392

Giessen, Germany

e-mail: torsten.will@agrar.

uni-giessen.de

tTorsten Will and Alexandra C. U.

Furch have contributed equally to the article.
Due to the high content of nutrient, sieve tubes are a primary target for pests, e.g., most phytophagous hemipteran. To protect the integrity of the sieve tubes as well as their content, plants possess diverse chemical and physical defense mechanisms. The latter mechanisms are important because they can potentially interfere with the food source accession of phloem-feeding insects. Physical defense mechanisms are based on callose as well as on proteins and often plug the sieve tube. Insects that feed from sieve tubes are potentially able to overwhelm these defense mechanisms using their saliva. Gel saliva forms a sheath in the apoplast around the stylet and is suggested to seal the stylet penetration site in the cell plasma membrane. In addition, watery saliva is secreted into penetrated cells including sieve elements; the presence of specific enzymes/effectors in this saliva is thought to interfere with plant defense responses. Here we detail several aspects of plant defense and discuss the interaction of plants and phloem-feeding insects. Recent agro-biotechnological phloem-located aphid control strategies are presented.

Keywords: aphid-plant interactions, aphid saliva, P-proteins, plant defense, phloem, sieve element occlusion
A key characteristic of higher-level plants (including monocots and dicots) is the existence of a vascular network that is composed of the phloem and xylem. The vascular system pervades the whole organism from root to shoot and distributes nutrients and water. The fact that sugars, amino acids, and other organic metabolites are available via phloem and xylem in significant amounts makes the vascular system a target for insect pests (Brodbeck et al., 1993; Gündüz and Douglas, 2009). Endogenous interference in the functioning of the vascular system may have disastrous consequences for a plant's development. Using the interaction between plants and phloem-feeding insects as an example, offensive and defense strategies during the struggle for the valuable phloem content are explored.

\section{THE PHLOEM: A HIGH-DENSITY ENERGY PATHWAY}

In higher-level plants, a long-distance transport system has evolved to translocate photoassimilates from a source (e.g., mature leaves) to a sink (e.g., roots) - the phloem (Schulz, 1998). The angiosperm phloem is composed of sieve elements (SEs), companion cells (CCs), and phloem parenchyma cells (PPCs; van Bel, 1996; Hafke et al., 2005). Mature SEs are elongate cells lacking certain cellular components (nucleus, vacuoles, ribosomes, and dictyosomes) but lined parietally with a thin mictoplasmic layer consisting of an endoplasmic reticulum (ER), plastids, a few inactive mitochondria and phloem-specific proteins (P-proteins; van Bel, 2003). The CCs maintain SEs viability (van Bel, 2003). A high density of pore-plasmodesma units (PPUs) and tight ER coupling between SE and CC underline an intimate symplastic connection across this boundary; the entire connection constitutes the SE-CC complex (Kempers et al., 1998; Martens et al., 2006). The walls between the single SE-modules are transformed into sieve plates, perforated by plasmodesmata (PD) modified into sieve pores with a diameter up to $2.5 \mu \mathrm{m}$ (Behnke and Sjolund, 1990; Schulz, 1998; van Bel, 2003; Mullendore et al., 2010). These adaptations provide the basis of formation of long sieve tubes based upon single SE-modules, forming a tube-like symplastic continuum that serves translocation. The complex process of this translocation is regulated via highly active CCs (van Bel and Knoblauch, 2000).

In general, the vascular system is a pressure system made up of two components (phloem and xylem) that effects the longdistance translocation of very heterogeneous constituents within higher-level plants. Xylem and phloem are parallel orientated vascular tissues in which pressure and tension gradients are built up in SEs and xylem vessels, respectively. In intact plants, the negative hydrostatic potential in xylem vessels is in balance with that inside SEs (e.g., Zimmermann et al., 2013). The driving forces for translocation are, on the one hand, a longitudinal (axial) pressure gradient within phloem and xylem, and on the other, a lateral (radial) pressure gradient between the phloem and xylem (Will and van Bel, 2006). The balanced interaction between phloem and xylem is a basic requirement for long-distance transport (van Bel, 2003; Dinant and Lemoine, 2010). The longitudinal pressure gradient within the xylem is the result of water uptake in the root/rhizosphere and loss of water by transpiration. According to the classic Münch concept (Münch, 1930) for phloem translocation, photoassimilates are amassed in the sieve tubes of 
source areas and escape from the sieve tubes in sink areas. The resulting turgor difference between source and sink drives the mass flow. Hence, in contrast to the xylem, the phloem exhibits a bidirectional translocation, as sink regions are found in the root and in the apex of the shoot (van Bel, 2003; Dinant and Lemoine, 2010).

Phloem sap contains carbohydrates, proteins, and amino acids (Table 1) and makes SEs a favorite target for pathogens and pests (Figure 1A). An accession of SEs by pathogens/pests leads to varies impairments: (a) loss of nutrients, (b) disturbance of the translocation process, and (c) the infection by microbial pathogens (e.g., viruses, phytoplasmas, viroids; Dinant et al., 2010; Giordanengo et al., 2010). Therefore, plants have evolved a range of defense mechanisms against pathogens and pests, which in turn possess mechanisms with which to counteract these defenses.

\section{"PLANTS IN ACTION": THE OCCLUSION OF SIEVE TUBES IS PROTECTIVE}

Damage of sieve tubes disturbs the existing pressure conditions resulting in a turgor shift (Gould et al., 2004), which impact intracellular calcium levels and the redox state. Long-distance signaling by electropotential waves (EPWs) communicates local wounding to distant plant parts (van Bel and Gaupels, 2004; Furch et al., 2007, 2009, 2010; Zimmermann and Mithöfer, 2013). This induces the occlusion of sieve tubes via the plugging of sieve pores and can be seen as primary defense response (Knoblauch and van Bel, 1998). Sieve-tube occlusion is assumed to prevent the loss of sieve-tube sap (Evert, 1982; Schulz, 1998) and to keep phytopathogens from invading through the injured site (van Bel, 2003). Two groups of sieve-tube occlusion mechanisms can be found in plants: callose

Table 1 | Aphid nutrition-related compounds and defense relevant factors of phloem sap.

\begin{tabular}{|c|c|c|c|}
\hline \multicolumn{4}{|c|}{ Aphid nutrition-related compounds } \\
\hline Constituent & Concentration & Species & Reference \\
\hline \multicolumn{4}{|l|}{ C-source } \\
\hline Sucrose & $\begin{array}{l}100-1800 \mathrm{mM} \\
(\varnothing 300-700 \mathrm{mM})\end{array}$ & $\begin{array}{l}\text { Triticum aestivum; Orzya sativa; Opuntia } \\
\text { ficus-indica; Sonchus oleraceus; Medicago } \\
\text { sativa; Salix viminalis; Solanum tuberosum; } \\
\text { Brassica sp.; Plantago major; Plantago } \\
\text { maritime; Prunus persica; Apium graveolens }\end{array}$ & $\begin{array}{l}\text { Rogers and Peel (1975); Hayashi and Chino (1986) } \\
\text { Hayashi and Chino (1990); Girousse etal. (1991), } \\
\text { Wang and Nobel (1995); Lohaus and Moellers } \\
\text { (2000), } \\
\text { Gould et al. (2004); Shimada etal. (2004), } \\
\text { Pescod et al. (2007), } \\
\text { Nadwodnik and Lohaus (2008) }\end{array}$ \\
\hline Glucose & $400 \mathrm{mM}$ & Opuntia ficus-indica & Wang and Nobel (1995) \\
\hline Fructose & $400 \mathrm{mM}$ & Opuntia ficus-indica & Wang and Nobel (1995) \\
\hline Raffinose & $70 \mathrm{mM}$ & Cucurbita maxima & Haritatos etal. (1996) \\
\hline Stachyose & $330 \mathrm{mM}$ & Cucurbita maxima & Haritatos et al. (1996) \\
\hline $\begin{array}{l}\text { Carbohydrates } \\
\text { (total) }\end{array}$ & $\begin{array}{l}534-1800 \mathrm{mM} \\
(\varnothing 500-800 \mathrm{mM})\end{array}$ & $\begin{array}{l}\text { Lycopersicon esculentum; Alonsoa } \\
\text { meridionalis; Cucurbita maxima; Cucumis } \\
\text { melo }\end{array}$ & $\begin{array}{l}\text { Haritatos etal. (1996); Voitsekhovskaja et al. (2006), } \\
\text { Pescod et al. (2007); Turgeon and Wolf (2009), } \\
\text { Zhang etal. (2010) }\end{array}$ \\
\hline \multicolumn{4}{|l|}{$\mathbf{N}$ - source } \\
\hline Amino acids & $\begin{array}{l}41-1230 \mathrm{mM} \\
\text { (Ø200-500 mM) }\end{array}$ & $\begin{array}{l}\text { Zea mays; Triticum aestivum; Orzya sativa; } \\
\text { Opuntia ficus-indica; Pisum sativum; Medicago } \\
\text { sativa; Brassica napus; Brassica carinata }\end{array}$ & $\begin{array}{l}\text { Fukumorita and Chino (1982); Hayashi and Chino } \\
\text { (1986) } \\
\text { Hayashi and Chino (1990); Ohshima et al. (1990), } \\
\text { Girousse et al. (1991, 1996), } \\
\text { Wang and Nobel (1995); Lohaus et al. (1998), } \\
\text { Lohaus and Moellers (2000); Faria et al. (2007), } \\
\text { Gattolin et al. (2008) }\end{array}$ \\
\hline Proteins & $\begin{array}{l}76-77 \mu \mathrm{g} / \mathrm{ml} \\
0.1-0.2 \mu \mathrm{g} / \mu \mathrm{l}\end{array}$ & $\begin{array}{l}\text { Orzya sativa; Triticum aestivum; Opuntia } \\
\text { ficus-indica; Lupinus albus }\end{array}$ & $\begin{array}{l}\text { Wang and Nobel (1995), Schobert et al. (1998), } \\
\text { Rodriguez-Medina (2009) }\end{array}$ \\
\hline & & Defense relevant factors & \\
\hline $\mathrm{Ca}^{2+}$ & $35 \mathrm{nM}$ to $2.5 \mathrm{mM}$ & Zea mays; Vicia faba & Fromm and Bauer (1994); Furch et al. (2009) \\
\hline Turgor pressure & 5-20 bar & $\begin{array}{l}\text { Quercus rubrum; Sonchus oleraceus; } \\
\text { Salix babylonica }\end{array}$ & $\begin{array}{l}\text { Hammel (1968); Wright and Fisher (1980), } \\
\text { Gould etal. (2004, 2005) }\end{array}$ \\
\hline
\end{tabular}

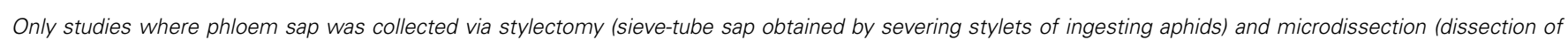
selected cells and subsequent analysis of cell content) were considered. 

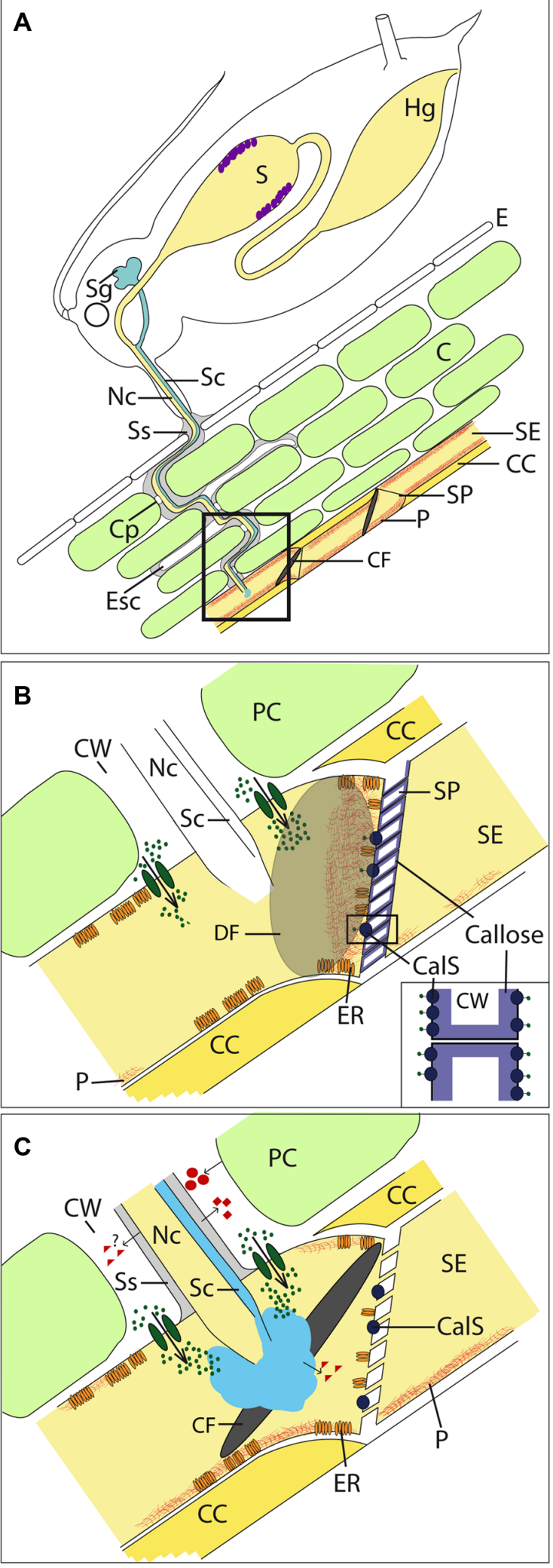

FIGURE 1 | Interaction of plants and aphids. (A) Aphids penetrate the plant with their stylet and move it through the apoplast toward the sieve

(Continued)

\section{FIGURE 1 | Continued}

tubes. The stylet contains a salivary (Sc) and nutrition channel (Nc). Before plant penetration and during stylet movement, aphids secrete gel saliva (gray), which forms a salivary sheath (Ss) around the stylet. The Ss remains in the plant's apoplast after stylet retraction and show empty stylet canals (Esc). After penetrating a sieve tube, aphids secrete watery saliva (light blue) prior to ingestion. Both saliva types are produced in the salivary glands (Sg). Proteases (violet dots) located in the stomach (S) are assumed to digest phloem-sap proteins. (B) The sieve tube penetration of the stylet without secretion of any saliva type would activate mechano-sensitive $\mathrm{Ca}^{2+}$ channels (dark green ovals) in the plasma membrane of sieve elements (SE). The consequence is a $\mathrm{Ca}^{2}+$ influx (dark green dots) from the apoplast and potentially from the endoplasmaic reticulum (ER) into the SE lumen. P-proteins $(P$, red) including the forisome and callose produced from the callose synthase (CalS; inset shows a higher magnification) lead to $\mathrm{Ca}^{2+}$ dependent sieve-element occlusion. (C) The secretion of gel and watery saliva most likely leads to an absence of wound-induced reaction of SEOs

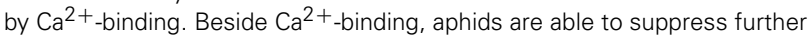
plant defense responses due to salivary effectors (red triangles).

Furthermore, plant defense responses are induced in parenchyma cells (PCs), among others, by producing cell wall degradation products that act as pathogen-induced molecular patterns (red circles). Saliva proteins may act as pathogen-associated molecular patterns (red squares). E, epidermis; C, cortex; CC, companion cell; $\mathrm{CF}$, condensed forisome; $\mathrm{Cp}$, cell penetration; $\mathrm{CW}$, cell wall; DF, dispersed forisome; $\mathrm{Hg}$, hint gut; $\mathrm{SP}$, sieve plate.

deposition and protein plugging (e.g., Will and van Bel, 2006; Furch et al., 2007).

\section{SIEVE-PORE CONSTRICTION BY CALLOSE: LONG-TERM MECHANISM}

Callose is a linear $\beta$-1,3-glucan polymer with some 1,6 branches. $\beta$-1,3-glucans are produced as helical chains which, upon heating, form a gel. It is produced enzymatically in the presence of $\mathrm{Ca}^{2+}$ by callose synthases, located in the plasma membrane, and deposited extracellularly around sieve pores (Figure 1B) and PD in the form of collars (Blackman and Overall, 1998; Zabotin et al., 2002) as a reaction to chemical or mechanical stress (Kudlicka and Brown, 1997; Nakashima et al., 2003; Levy et al., 2007). The pattern and timing of callose distribution and its physiological involvement suggest that callose plays an important part in plant cell growth and differentiation. In Arabidopsis, 12 callose synthase genes (CalS1-12) have been detected. CalS1 and CalS10 have been shown to be responsible for cell plate formation during cell division (Hong et al., 2001; Thiele et al., 2008; Guseman et al., 2010). CalS5, CalS9, CalS10, CalS11, and CalS12 play unique roles during microsporogenesis and pollination (Dong et al., 2005; Enns et al., 2005; Nishikawa et al., 2005; Töller et al., 2008; Huang et al., 2009; Xie etal., 2010). CalS12 can be induced by pathogen infection and wounding (Jacobs et al., 2003; Nishimura et al., 2003; Dong et al., 2008), and CalS7 deposits callose in the phloem (Figure 1B; Xie et al., 2011). Xie et al. (2011) showed that callose deposition in the phloem, especially in the SEs, was greatly reduced in cs7 mutants. Callose accumulation was eliminated in the PDs of incipient sieve plates resulting in fewer sieve pores of cs7 mutants. They conclude that CalS7 is a phloem-specific callose synthase gene, and is responsible for callose deposition in developing SEs during phloem formation and in mature phloem induced by wounding. The physiological roles of the remaining CalS genes in Arabidopsis are still unknown.

Callose deposition is a universally observed mode of sieve-plate occlusion (Kudlicka and Brown, 1997; Nakashima et al., 2003). 
Reversible callose accumulation apparently plays a role in regulating cell-to-cell transport through sieve pores and PPUs (Furch etal., 2007). After a heat stimulus is applied to the leaf tip of Vicia faba plants, callose gradually builds up at sieve plates and PD. After reaching a maximum, callose is degraded at a lower rate than production. Callose appears to degrade more rapidly at $\mathrm{PD}$ (30-40 $\mathrm{min}$ ) than at the sieve pores, where the level of callose deposition reaches its original state after 1-2 h (Furch et al., 2007). $\beta$-1,3-glucan endo-hydrolases is the enzyme that catalyses callose degradation (reviewed in Leubner-Metzger, 2003). It is present in large gene families in plants (e.g., 50 genes in Arabidopsis) and is located in the cell membrane and highly enriched at PD sites (Levy et al., 2007). The course of callose production/degradation is qualitatively similar between different plant species, but there are variations in the time scale (Furch et al., 2007, 2008; Mullendore et al., 2010).

\section{SIEVE-TUBE OCCLUSION BY PROTEINS: FAST AND VERSATILE}

In addition to callose, sieve pores can be blocked rapidly by proteins. In electron microscopic images, SEs show protein networks that span the SE lumen and are attached to the cell periphery (Sjölund, 1997). Sieve tubes of grasses appear virtually empty but may have an occlusion mechanism based on precipitation of soluble proteins (Will and van Bel, 2006). A specific group of phloem proteins (P-proteins) enables rapid occlusion (within some seconds) to occur in sieve tubes of higher-level plants. Numerous aggregation forms (amorphous, granular, fibrillar, filamentous, tubular, or crystalline) of P-proteins that are thought to represent stages of P-protein differentiation (Cronshaw, 1981) denote an immense variation between plant species (Cronshaw and Sabnis, 1990). The synthesis of P-proteins begins in immature, nucleate SEs, resulting in electron-dense proteinaceous structures (Ernst et al., 2012). In young SEs, subunits accumulate within the cytoplasm, forming large P-protein bodies (Steer and Newcomb, 1969). As SEs mature the P-protein bodies disperse into smaller aggregates that move to the periphery of the cell (Knoblauch and van Bel, 1998).

In cucurbits, phloem protein 1 (PP1) and phloem protein 2 (PP2) produce insoluble aggregates in response to oxidation (Kleinig, 1975; Alosi et al., 1988) by cross-linking, forming highmolecular-weight polymers that plug the sieve pores of injured sieve tubes (Read and Northcote, 1983). PP1 monomeric subunits have a predicted molecular mass of $95.4 \mathrm{kDa}$, but the apparent molecular size is dependent on the $\mathrm{pH}$ and oxidation state, as conformational isoforms exist that appear to be related to either the polymerized or unpolymerized, translocated forms of the protein (Clark et al., 1997; Leineweber et al., 2000). PP1 was immunolocalized in SE slime plugs and P-protein bodies, whereas the corresponding mRNA was shown to accumulate in CCs (Clark et al., 1997). Due to an interaction of PP1 and PP2 in presence of calcium and oxygen, sieve tubes and cut surfaces are rapidly occluded by gelling of the exudate (Kleinig, 1975; Clark et al., 1997; Furch et al., 2010). PP2-like proteins are lectins, sugar binding proteins, which have been identified in many angiosperms and are specifically expressed in SE/CC complexes, suggesting that PP2 may be a common component of P-proteins (Dinant et al., 2003). It has been shown to interact with phloem sap proteins, potentially playing a role in the shuttling of glycoproteins between CC and SE (Beneteau et al., 2010). The phloem-specific PP2 homolog from Arabidopsis was shown to be anchored to P-proteins and other phloem organelles rather than being a structural component of P-proteins (Batailler et al., 2012). These findings indicate that PP2 does not represent an essential part of the occlusion machinery. An insecticidal function for PP2 is described in vitro (Beneteau et al., 2010) as well as in vivo (Zhang et al., 2011). Hilder et al. (1995) observed that snowdrop lectin from Galanthus nivalis, artificially applied or expressed in Nicotiana tabacum plants, reduced growth, decreased survival, and lowered reproduction in the aphid species Myzus persicae. Other lectins that showed insecticidal effects against aphids are a mannose-binding lectin (Sauvion et al., 1996), a garlic lectin (Fitches et al., 2008), and concanavalin A (Sauvion et al., 2004). Similar effects were observed for protease inhibitors (PIs) applied to aphids via transgenic plants (Rahbé et al., 2003; Ribeiro et al., 2006; Carrillo et al., 2011). Erickson et al. (1985) observed that lectins negatively affect the activity of an aminopeptidase in rats. The identified aminopeptidase inside the aphid gut, which represents $15.6 \%$ of total gut proteins, is suggested to be a potential binding site for lectins (Cristofoletti et al., 2006).

Sieve elements of Fabaceae contain elongate protein bodies called forisomes (Knoblauch et al., 2003). Forisomes consist of fibrils (Tuteja et al., 2010) and were previously classified as "nondispersive P-protein bodies” (Behnke, 1991). They were suspected to undergo structural transformations, from a crystalloid state with co-aligned fibrils to a "slime-body" with dispersed fibrils (Palevitz and Newcomb, 1971). The transition is a rapid and reversible conformational change in which forisomes shorten longitudinally while expanding radially with a several-fold volume increase (Knoblauch et al., 2001; Peters et al., 2007, 2008). Forisomes disperse upon wounding and occlude sieve tubes (Knoblauch and van Bel, 1998), leading to a stop of mass flow observed in artificial sieve tubes (Knoblauch et al., 2012). Furthermore, Thorpe et al. (2010) showed a cooling rate dependent transport interruption and parallel forisome dispersion in intact $V$. faba plants. Dispersion is triggered by an increase of free calcium $\left(\mathrm{Ca}^{2+}\right)$ in sieve tubes (Knoblauch et al., 2001), although as of yet, no $\mathrm{Ca}^{2+}$-binding sites have been detected in forisomes. As observed in vitro (Knoblauch et al., 2005), high $\mathrm{Ca}^{2+}$ concentration $(>50 \mu \mathrm{M})$ is also needed to disperse forisome in vivo (Furch et al., 2009). After burning the tip of a $V$. faba leaf, the elevation of $\mathrm{Ca}^{2+}$ concentration in most regions of sieve tubes inside the respective leaf was demonstrated to be below the threshold that is necessary for forisome dispersion (Furch etal., 2009). Only in the close vicinity of the $\mathrm{Ca}^{2+}$-channel pore $\mathrm{Ca}^{2+}$-level goes beyond the threshold and increases up to 100 MM (Figure 1B; Trewavas, 1999). Therefore, it was concluded that forisomes are directly associated with $\mathrm{Ca}^{2+}$ release sites (Furch et al., 2009). An association between forisomes and the ER (where the highest frequencies of $\mathrm{Ca}^{2+}$ channels were observed) was found. It was observed that the more intimately forisomes were associated with the ER or the plasma membrane of SEs, the greater was the probability of dispersion (Furch et al., 2009).

Scanning electron microscopic images show that forisomes are composed of largely identical subunits named forisomettes (Tuteja 
et al., 2010). Indicated by transmission electron microscopy studies (Ehlers et al., 2000), forisomettes consist of strictly ordered arrays of a number of forisome proteins. At least three proteins are involved in formation of forisomettes, called sieve element occlusion 1 (SEO1), SEO2, and SEO3, and were identified in Medicago truncatula (Noll, 2005; Noll et al., 2007). SEOs are also present in plant families that do not possess forisomes, e.g., Rosaceae, Solanaceae, and Brassicaceae (Rüping et al., 2010). Two Arabidopsis thaliana genes (At3g01670 and At3g01680) encode SEO proteins assigned AtSEOR1 and AtSEOR2 (Pélissier et al., 2008; Rüping etal., 2010; Froelich etal., 2011). Both phloem filament proteins are required for formation of filaments that are arranged as complex network inside SEs (Anstead et al., 2012). Whether the formation of dense SEO filament deposits at sieve plates stops phloem mass flow (Figure 1B; Ernst et al., 2012) or mass flow remains intact (Froelich et al., 2011) is a matter of debate. Aphids of the species Myzus persicae that feed on AtSEOR1 and AtSEOR2 mutants without SEO filament formation show no benefit from the absence of filaments. Thus, Anstead et al. (2012) conclude that SEOs are not involved in plant defense against phloem-feeding insects. In fact, aphids perform worse when compared to aphids on control plants, indicated by reduced reproduction and shortened reproduction period. The authors suggest that reduced fitness could be associated with lower nitrogen supply due to reduced protein content, but no data about amino acid concentration or protein content in the phloem sap of these plants are available. A further explanation could be that the absence of SEO filaments influences parameters in sieve tubes relevant for aphid feeding, e.g., turgor pressure (Miles, 1999), reducing nutrition supply and leading to the observed reduction of aphid reproduction. Although, Anstead et al. (2012) describe that the phenotype SEO mutants does not differ to the wildtype this allows no conclusion about the state of sieve tubes.

Callose deposition and protein plugging operate in parallel. A burning stimulus elicits distant occlusion in $V$. faba with rapid forisome dispersion and a slower subsequent callose deposition (Furch et al., 2007, 2009). While forisomes reconstitute into the condensed state, constriction of sieve pores by callose deposition reaches its maximum level (Furch et al., 2007). It is suggested, therefore, that plants possess a universal safety design for sievetube occlusion, one that proceeds rapidly and involves P-protein and a slower and more long-lasting one based on callose (Furch et al., 2007).

The distant-induced occlusion was associated with the passage of a damage-induced EPW. EPWs communicate sudden and profound physiological changes over long-distances (Furch et al., 2007; Hafke et al., 2009). EPWs trigger a release of $\mathrm{Ca}^{2+}$ that results in callose deposition and protein plugging (Kauss, 1987; Colombani et al., 2004). $\mathrm{Ca}^{2+}$ originates from the apoplast via opened plasma membrane channels or from the ER acting as an intracellular $\mathrm{Ca}^{2+}$ storage (Furch et al., 2009; Hafke et al., 2009; Zimmermann and Mithöfer, 2013).

\section{"INSECTS IN ACTION": HOW PHLOEM-FEEDING INSECTS OVERWHELM PLANT DEFENSES}

Phloem-feeding insects belong to the order Hemiptera. Of these, important pests are planthoppers (suborder Auchenorrhyncha) and leafhoppers (suborder Clypeorrhyncha) as well as aphids and whiteflies (suborder Sternorrhyncha). The most currently available information about interaction with plants is on aphids, which make them a model organism for phloem feeders. Phloemfeeding insects possess specialized mouthparts, so-called stylets, with which they are able to obtain nutrition from plant tissues that are located deep inside the plant (Figure 1A). To access their food source, phloem-feeding insects secrete saliva that potentially interacts with defense mechanisms located in the sieve tube (Tjallingii, 2006; Will and van Bel, 2006).

\section{THE STYLET AND ITS PATHWAY}

The thin stylets of phloem-feeding insects are formed of four subunits, and their diameter and length are species dependent. The two outer mandibular parts contain nerve canals; the inner maxillary parts form the nutrition channel and a saliva channel that merge to a common duct at the tip of the stylet (Uzest et al., 2010). An insect penetrates the plant with its stylet and moves the stylet toward the sieve tubes (Figure 1A). The stylet moves through the apoplast without causing significant damage to plant cells (Tjallingii and Esch, 1993; Hewer et al., 2011). Plant cells of different cell types are regularly penetrated along the stylet track. Aphids take up small cell sap samples when penetrating; this sample is most likely analyzed by chemosensilla in the precibarium (Wensler and Filshie, 1969) as observed for leafhoppers (Backus and McLean, 1985). Beside acceptance of host plants (Backus and McLean, 1985) this behavior could allow aphids to orient themselves inside the plant and helps them to detect sieve tubes, whereat parameters like sucrose and $\mathrm{pH}$ (Table 1) are suggested to be indicators for sieve tube penetration (Hewer et al., 2010, 2011). After a sieve tube is penetrated, ingestion starts.

\section{SALIVA AND ITS RELEVANCE FOR APHID-PLANT INTERACTIONS}

Before plant penetration with their stylets, during stylet movement through the apoplast, penetration of cells, and ingestion, saliva is secreted by planthoppers (Wang et al., 2008), leafhoppers (Günthardt and Wanner, 1981; Harris et al., 1981; DeLay et al., 2012), aphids (Prado and Tjallingii, 1994; Tjallingii, 2006) as well as whiteflies (Morgan et al., 2013). Saliva has been suggested to play a key role in the interaction of insect pests and their respective host plants (reviewed in Walling, 2008). Aphids in particular function as model organisms for studying both phloem-feeding insects and the role and functions of saliva inside the plant. Like other hemiptera, aphids possess two types of saliva, one gel-like and one watery (Miles, 1999), although recently the protein composition of both types was shown to overlap partly (Will et al., 2012a).

Gel saliva forms a salivary flange on the plant surface prior to plant penetration (Figure 1A; Will et al., 2012b), which is suggested to stabilize the stylet before initiating stylet penetration of the plant (Pollard, 1973; Tjallingii, 2006). When the stylet moves, small amounts of gel saliva are secreted; these harden and are then penetrated by the stylet (McLean and Kinsey, 1965). This continuous secretion of gel saliva leads to the formation of a solid salivary sheath that envelops the stylet and is left in situ after it is withdrawn from plant tissues (Will et al., 2012b). Sheath formation was assumed to be associated with the oxidation of protein sulphydryl groups, e.g., present in the amino acid cysteine (Miles, 
1965; Tjallingii, 2006). Will et al. (2012a) observed in this context that salivary sheath formation is disturbed under anoxic conditions. A protein that possesses a high content of cysteine was identified in saliva of the pea aphid Acyrthosiphon pisum by Carolan et al. (2009) and termed "sheath protein" (SHP). It is assumed that formation of disulfide bonds leads to SHP aggregation and formation of the solid sheath. The fact that most phytophagous hemiptera were observed to form a salivary sheath during the feeding process (Morgan et al., 2013), implies biological relevance but specific functions are unknown.

It is suggested that gel saliva functions as a lubricant to facilitate stylet movement and that the sheath protects the stylet against mechanical forces and chemicals (Miles, 1999). Furthermore, Will and van Bel (2006) postulated that the salivary sheath prevents the induction of defense responses in these conduits. In contrast, some enzyme components of the gel saliva are assumed to trigger plant defense responses by forming so-called pathogen-induced molecular patterns (PIMPs; Figure 1C). Potential candidates for PIMP production are cell-wall-degrading enzymes, such as cellulase and pectinase, which were detected in aphid saliva (Ma et al., 1990; Cherqui and Tjallingii, 2000). Whether the protein or peptide components of gel saliva act in a similar manner to, e.g., flg22 from bacteria (Zipfel, 2008) as pathogen-associated molecular patterns (PAMPs; Figure 1C) that trigger plant defense responses in a gene-to-gene interaction can be speculated (Will et al., 2012b). It may be that aphid gel saliva on one hand induces plant defense in cortex cells along the stylet track and on the other hand suppresses defense inside penetrated sieve tubes (Figure 1C; Will and van Bel, 2008; Louis et al., 2012).

Aphid watery saliva is secreted intracellularly, either when the stylets briefly puncture cells during probing (Martin et al., 1997) or immediately before and during sap ingestion (Figure 1C; Prado and Tjallingii, 1994), and recent studies on Aphis gossypii indicate that watery saliva is secreted into the apoplast as well (Moreno et al., 2011). Gel saliva and watery saliva contain many different proteins of a broad molecular weight range (e.g., Madhusudhan and Miles, 1998; Will et al., 2007, 2009; Harmel et al., 2008; Carolan et al., 2009; Cooper et al., 2011; Nicholson et al., 2012). The main classes of proteins that were identified with a proteomic approach in the species Acyrthosiphon pisum are proteases, detoxifying enzymes and proteins that potentially interact with plant signaling cascades, so-called effectors (Carolan et al., 2011). Salivary proteins appear to move from the SE where they were secreted into adjacent SEs (Madhusudhan and Miles, 1998), which suggests that saliva functions are not restricted to an aphid-penetrated SE. Thus, the activity of aphids in a population puncturing SEs downstream from an SE already punctured by another aphid may be facilitated by suppressed defense responses. The aphids may therefore benefit from the saliva secretions of other individuals. The observation that feeding is locally stimulated on potato for the aphid species Myzus persicae and Macrosiphon euphorbiae, respectively, $96 \mathrm{~h}$ after first infestation (Dugravot et al., 2007) supports this hypothesis.

\section{INTERACTION WITH OCCLUSION AND SIGNALING}

Sieve tubes lack most organelles and gene expression machinery but possess a variety of defense components, both physical and chemical mechanisms. $\mathrm{Ca}^{2+}$ represents a core of both groups (Figure 1B). The high concentration gradient of $\mathrm{Ca}^{2+}$ between apoplast and SE lumen leads to an influx of $\mathrm{Ca}^{2+}$ into the SE lumen during penetration of the SE membrane by a thin glass capillary, which induces occlusion (Figure 1B; Knoblauch and van Bel, 1998). During SE penetration by an aphid stylet this transient event is assumed to be suppressed initially by gel saliva that is secreted prior to penetration and seals the penetration site (Figure 1C; Will and van Bel, 2006). Walker and Medina-Ortega (2012) did not observe forisome dispersion in penetrated SEs prior to secretion of watery saliva and concluded that SE occlusion does not represent a defense mechanism against aphids, which is also suggested by Anstead et al. (2012). Nevertheless, findings of Walker and Medina-Ortega (2012) support the hypothesis that sealing of the stylet penetration site by gel saliva already mediates suppression of occlusion mechanisms (Figure 1C). The risk of triggering SE occlusion also occurs when aphids start to remove solute from the SE lumen, as this too potentially decreases turgor in SEs (Table 1) and thus activates potential mechano-sensitive $\mathrm{Ca}^{2+}$ channels that results, e.g., in forisome dispersion (Knoblauch et al., 2001; Furch et al., 2009). For this reason, in a second step prior to ingestion, aphids secrete watery saliva (Figure 1C) that contains proteins that bind $\mathrm{Ca}^{2+}$; these proteins were detected by functional analysis for the aphid species Megoura viciae and were shown to counteract SE occlusion (Will et al., 2007). Because aphids of different species change to watery saliva secretion if an occlusion event is induced during ingestion, the phenomenon of counteracting SE occlusion by secreting watery saliva is likely widespread (Will et al., 2009). In vitro experiments have demonstrated that this change of behavior is triggered by a decrease of turgor pressure inside the sieve tubes (Will et al., 2008) that is the consequence of SE occlusion (Gould et al., 2004).

In the saliva of Acyrthosiphon pisum, a $\mathrm{Ca}^{2+}$-binding protein was detected by mass spectrometry and was identified as regucalcin (Carolan et al., 2009). The molecular mass of this protein, $43 \mathrm{kDa}$, is comparable to that of a previously detected $\mathrm{Ca}^{2+}$-binding protein (Will et al., 2007). Regucalcin is a member of the senescence marker protein-30 (SMP-30) family that helps sequester signaling molecules such as $\mathrm{Ca}^{2+}$ (Fujita et al., 1992; Shimokawa and Yamaguchi, 1993). In addition, regucalcin maintains intracellular $\mathrm{Ca}^{2+}$ homeostasis by activating $\mathrm{Ca}^{2+}$ pumps in the plasma membrane, ER, and mitochondria of many animal cell types (Yamaguchi, 2000). Moreover, in animals regucalcin has an inhibitory effect on the activation of $\mathrm{Ca}^{2+} /$ calmodulin-dependent enzymes and protein kinase C (Yamaguchi, 2005). Thus, an inhibition of signaling cascades due to $\mathrm{Ca}^{2+}$-binding by saliva proteins appears likely (Will and van Bel, 2006, 2008), although little information about the molecular level of defense signaling inside sieve tubes is available. A recent study by Rao et al. (2013) did not detect the presence of regucalcin in the saliva of cereal aphids and the authors suggest that different protein compositions of watery saliva of various aphid species may illustrate the insects' adaptation to various host plants.

Other aphid species than Megoura viciae and Acyrthosiphon pisum, were not screened for $\mathrm{Ca}^{2+}$-binding proteins in their watery saliva. A $\mathrm{Ca}^{2+}$-binding protein was also identified in saliva of the green rice leafhopper; that this insect's saliva was 
secreted into sieve tubes may indicate the presence of comparable mechanisms in different groups of phloem-feeding insects (Hattori et al., 2012). Previously, Hao et al. (2008) demonstrated that the brown planthopper Nilaparvata lugens activates callose synthases during plant infestation but is able to unplug sieve pores by activating $\beta$-1,3-glucanases. Whether aphids also influence filament formation of SEO proteins (Batailler et al., 2012) or influence callose degradation is currently unknown.

\section{INTERACTION WITH CHEMICAL DEFENSE}

Several detoxifying proteins in the saliva of aphids were identified by enzymatic essays and novel approaches, including mass spectrometry. The detoxification of phenols by the secretion of polyphenoloxidase and peroxidase was reported for Sitobion avenae (Urbanska et al., 1998). The degradation of hydrogen peroxide could most likely interfere with defense signaling because hydrogen peroxide represents an activator of $\mathrm{Ca}^{2+}$ channels in the plasma membrane (Lecourieux et al., 2006).

Proteins that appear to interact directly with plant defense signaling are glucose dehydrogenase and glucose oxidase that were detected in the aphid species Myzus persicae and Acyrthosiphon pisum (Harmel et al., 2008; Carolan et al., 2011). Both potentially interfere with jasmonic acid (JA)-regulated defense responses that were shown to be induced during infestation of Arabidopsis by Brevicoryne brassicae (Kusnierczyk et al., 2011). Takemoto et al. (2013) noticed that endogenous JA production was less for Acyrthosiphon pisum infested broad bean plants. Furthermore, aphids appear to be able to modulate genes in the salicylic acid (SA) pathway (Zhu-Salzman etal., 2004). Cross-talk between JA and SA defense pathways (Pieterse et al., 2012) may allow aphids to suppress specific plant defense responses as has been previously described for whiteflies by Zarate et al. (2007). The role of SA and JA in plant-aphid interaction is reviewed by Louis and Shah (2013).

\section{SALIVARY EFFECTORS}

Effectors are defined as proteins and/or small molecules that modify cell structure and function inside the host of a pathogen (Hogenhout etal., 2009). Aphid species were shown to pursue similar strategies and secrete effectors as components of their saliva (Figure 1C). Effectors in saliva were first shown for Megoura viciae by identifying proteins that bind $\mathrm{Ca}^{2+}$ (Will et al., 2007). Later it was shown that C002, a salivary protein that is secreted into the sieve tubes by Acyrthosiphon pisum, plays an important role in aphid feeding (Mutti et al., 2008). If C002 is silenced by RNA interference (RNAi) in Acyrthosiphon pisum, aphids' life spans are reduced because they have problems reaching the sieve tubes and are thus unable to sustain ingestion (Mutti et al., 2006, 2008). Silencing of C002 homolog in Myzus persicae by feeding on transgenic plants showed lower aphid reproduction rates than usual but no overall change in survival rates (Pitino et al., 2011). When Myzus persicae fed on MpC002-expressing plants, an enhanced fecundity was observed (Bos et al., 2010), while the reproduction rates of Myzus persicae feeding on plants that express C002 from Acyrthosiphon pisum are not influenced (Pitino and Hogenhout, 2013). Further effectors with beneficial effect on aphid reproduction and thus on colonization are PIntO1 and PIntO2. Orthologs of C002, $\mathrm{PIntO} 1$ and $\mathrm{PIntO} 2$ were detected in salivary gland transcriptome of multiple aphid species and appear to be specific for the respective aphid species (Pitino and Hogenhout, 2013). A recent study of the effector Me23 shows that effectors are specific not only to aphid but also to plant by demonstrating that the fecundity of Macrosiphon euphorbiae was enhanced when aphids fed on Me23 expressing Nicotiana benthamiana and not on Me23 expressing tomato (Atamian et al., 2013). Above described effectors may be able to facilitate ingestion by suppressing plant defense responses, perhaps by interfering with signal cascades as described for different fungi (reviewed in Stergiopoulos and de Wit, 2009) and appear to contribute to aphid-plant compatibility (Pitino and Hogenhout, 2013). In addition to effectors that promote aphid colonization, some effectors induce plant defense responses. MP10 and MP42 were shown to reduce fecundity when expressed in plants (Bos et al., 2010), possibly interacting with plant receptors of the NBS-LRR superfamily and thus triggering plant defense responses (Hogenhout and Bos, 2011). The identified aphid resistance genes $\mathrm{Mi}-1.2$ in tomato (Martinez de Ilarduya etal., 2003) and Vat in melon (Dogimont et al., 2008) belong to the NBS-LRR receptor family (reviewed in Smith and Clement, 2012).

\section{PHLOEM-LOCATED APHID CONTROL STRATEGIES}

As described, plant defense can be overwhelmed by aphids. For this reason, e.g., agro-biotechnological control strategies support plant defense by inserting additional insecticidal compounds into the sieve tubes. Approaches are the expression of PIs and antimicrobial peptides (AMPs) that naturally do not belong to the target plants defense system (reviewed in Will and Vilcinskas, 2013). PIs can be used to target proteases detected in the watery saliva (Carolan et al., 2009) and alimentary tract (Rahbé et al., 1995; Cristofoletti et al., 2003, 2006) of aphids; there the PIs may prevent the digestion of proteins within the sieve-tube sap (Table 1). Although for a long time researchers did not believe that aphids were able to use proteins as a source of nutrition, new findings show that aphids can digest proteins in sieve-tube sap (Pyati et al., 2011). The use of AMPs represents an approach that targets the endosymbiotic bacteria of aphids, assuming that disrupting these bacteria would negatively affect aphid fitness (Douglas, 2007). The primary (obligate) endosymbiotic bacteria Buchnera aphidicola (Baumann et al., 1995) improves the quality of aphid diet by supplying it with essential amino acids (IAGC, 2010) that are absent in sieve-tube sap (Gündüz and Douglas, 2009). Other endosymbiotic bacteria improve aphid fitness by giving resistance to pathogenic fungi (e.g., Lukasik et al., 2012) or increasing thermo tolerance (e.g., Russell and Moran, 2006). Although described methods of controlling aphids address different levels of interaction of pests and their respective host plants, a common goal is disrupting plant accession and nutrition uptake. Expressing defense agents in the sieve tubes is an effective way of accomplishing this disruption. Defense agents negatively affect fitness parameters (e.g., Le-Feuvre et al., 2007; Mutti etal., 2008; Pyati etal., 2011), such as growth, reproduction, and survival, which may reduce infestations among plants. 


\section{ACKNOWLEDGMENTS}

Torsten Will acknowledges funding from the Hessian Ministry of Science and Art (HMWK) via the LOEWE research focus "Insect Biotechnology." Alexandra C. U. Furch thanks funding by the Justus-Liebig University in the frame of "Just'us postdoc grant" and "Margarete Bieber grant." We thank the reviewers for valuable comments and Emily Wheeler for editorial assistance.

\section{REFERENCES}

Alosi, M. C., Melroy, D. L., and Park, R. B. (1988). The regulation of gelation of phloem exudates from Cucurbita fruit by dilution, glutathione, and glutathione reductase. Plant Physiol. 86, 1089-1094. doi: 10.1104/pp.86.4.1089

Anstead, J. A., Froelich, D. R., Knoblauch, M., and Thompson, G. A. (2012). Arabidopsis P-protein filament formation requires both AtSEOR1 and AtSEOR2. Plant Cell Physiol. 53, 1033-1042. doi: 10.1093/pcp/pcs046

Atamian, H. S., Chaudhary, R., Dal Chin, V., Bao, E., Girke, T., and Kaloshian, I. (2013). In planta expression or delivery of potato aphid Macrosiphum euphorbiae effectors Me10 and Me23 enhances aphid fecundity. Mol. Plant Microbe Interact. 26, 67-74. doi: 10.1094/MPMI06-12-0144-FI

Backus, E. A., and McLean, D. L. (1985). Behavioral evidence that the precibarial sensilla of leafhoppers are chemosensory and function in host discrimination. Entomol. Exp. Appl. 37, 219-228. doi: 10.1111/j.15707458.1985.tb03478.x

Batailler, B., Lemaître, T., Vilaine, F., Sanchez, C., Renard, D., Cayla, T., etal. (2012). Soluble and filamentous proteins in Arabidopsis sieve elements. Plant Cell Environ. 35, 1258-1273. doi: 10.1111/j.13653040.2012.02487.x

Baumann, P., Baumann, L., Lai, C.-Y., and Rouhbakhsh, D. (1995). Genetics, physiology, and evolutionary relationships of the genus Buchnera: intracellular symbionts of aphids. Annu. Rev. Microbiol. 49, 55-94. doi: 10.1146/annurev.mi.49.100195. 000415

Behnke, H. D. (1991). Non dispersive protein bodies in sieve elements: a survey and review of their origin, distribution, and taxonomic significance. IAWA Bull.12, 143-175.

Behnke, H. D., and Sjolund, R. D. (eds). (1990). Sieve Elements. Comparative Structure, Induction, and Development. Berlin: Springer-Verlag. doi: 10.1007/978-3-642-74445-7

Beneteau, J., Renard, D., Marche, L., Douville, E., Lavenant, L., Rahbe, Y., etal. (2010). Binding properties of the $N$-acetylglucosamine and high-mannose $N$-glycan PP2A1 phloem lectin in Arabidopsis.
Plant Physiol. 153, 1345-1361. doi: 10.1104/pp.110.153882

Blackman, L. M., and Overall, R. L. (1998). Immunolocalisation of the cytoskeleton to plasmodesmata of Chara corallina. Plant J. 14, 733-741. doi: 10.1046/j.1365313x.1998.00161.x

Bos, J. I. B., Prince, D., Pitino, M., Maffei, M. E., Win, J., and Hogenhout, S. A. (2010). A functional genomics approach identifies candidate effectors from the aphid species Myzus persicae (green peach aphid). PLoS Genet. 6:e1001216. doi: 10.1371/journal.pgen.1001216

Brodbeck, B. V., Mizell, R. F., and Andersen, P. C. (1993). Physiological and behavioral adaptations of three species of leafhoppers in response to the dilute nutrient content of xylem fluid. J. Insect Physiol. 39, 73-81. doi: 10.1016/0022-1910(93) 90020-R

Carolan, J. C., Caragea, D., Reardon, K. T., Mutti, N. S., Dittmer, N., Pappan, K., et al. (2011). Predicted effector molecules in the salivary secretome of the pea aphid (Acyrthosiphon pisum): a dual transcriptomic/proteomic approach. J. Proteome Res. 10, 1505-1518. doi: $10.1021 /$ pr100881q

Carolan, J. C., Fitzroy, C. I. J., Ashton, P. D., Douglas, A. E., and Wilkinson, T. L. (2009). The secreted salivary proteome of the pea aphid Acyrthosiphon pisum characterised by mass spectrometry. Proteomics 9, 2457-2467. doi: 10.1002/pmic. 200800692

Carrillo, L., Martinez, M., ÁlvarezAlfageme, F., Castanera, P., Smagghe, G., Diaz, I., et al. (2011). A barley cysteine-proteinase inhibitor reduces the performance of two aphid species in artificial diets and transgenic Arabidopsis plants. Transgenic Res. 20, 305-319. doi: 10.1007/s11248-0109417-2

Cherqui, A., and Tjallingii, W. F. (2000). Salivary proteins of aphids, a pilot study on identification, separation, and immunolocalisation. $J$. Insect Physiol. 46, 1177-1186. doi: 10.1016/S0022-1910(00)00037-8

Clark, A. M., Jacobsen, K. R., Bostwick, D. E., Dannenhoffer, J. M., Skaggs, M. I., and Thompson, G. A. (1997). Molecular characterization of a phloem-specific gene encoding the filament protein, phloem protein 1 (PP1), from Cucurbita maxima. Plant J. 12, 49-61. doi: 10.1046/j.1365-313X.1997.12010049.x Colombani, A., Dierbi, S., Bessueille, L., Blomqvist, K., Ohlsson, A., Berglund, T., etal. (2004). In vitro synthesis of $(1 \rightarrow 3)-\beta$-Dglucan (callose) and cellulose by detergent extracts of membranes from cell suspension cultures of hybrid aspen. Cellulose 11, 313-327. doi: 10.1023/B:CELL.0000046404. 25406.19

Cooper, W. R., Dillwith, J. W., and Puterka, G. J. (2011). Comparisons of salivary proteins from five aphid (Hemiptera: Aphididae) species. Environ. Entomol. 40, 151-156. doi: 10.1603/EN10153

Cristofoletti, P. T., Mendonca de Sousa, F. A., Rahbé, Y., and Terra, W. R. (2006). Characterisation of a membrane-bound aminopeptidase purified from Acyrthosiphon pisum midgut cells. FEBS J. 273, 5574-5598. doi: 10.1111/j.17424658.2006.05547.x

Cristofoletti, P. T., Ribeiro, A. F., Deraison, C., Rahbé, Y., and Terra, W. R. (2003). Midgut adaptation and digestive enzyme distribution in a phloem feeding insect, the pea aphid Acyrthosiphon pisum. J. Insect Physiol. 49, 11-24. doi: 10.1016/S0022 1910(02)00222-6

Cronshaw, J. (1981). Phloem structure and function. Annu. Rev. Plant Physiol. 32, 465-484. doi: 10.1146/annurev.pp.32.060181. 002341

Cronshaw, J., and Sabnis, D. D. (1990). "Phloem proteins," in Sieve elements. Comparative Structure, Induction, and Development, eds H. D. Behnke and R. D. Sjolund (Berlin: Springer-Verlag), 257-283.

DeLay, B., Mamidala, P., Wijeratne, A., Wijeratne, S., Mittapalli, O., Wang, J., et al. (2012). Transcriptome analysis of the salivary glands of potato leafhopper, Empoasca fabae. J. Insect Physiol. 58, 1626-1634. doi: 10.1016/j.jinsphys.2012.10.002

Dinant, S., Bonnemain, J.-L., Girousse, C., and Kehr, J. (2010). Phloem sap intricacy and interplay with aphid feeding. C. R. Biol.333, 504-515. doi: 10.1016/j.crvi.2010.03.008

Dinant, S., Clark, A. M., Zhu, Y., Vilaine, F., Palauqui, J. C., Kusiak, C., et al. (2003). Diversity of the superfamily of phloem lectins (phloem protein 2) in angiosperms. Plant Physiol.
131, 114-128. doi: 10.1104/pp. 013086

Dinant, S., and Lemoine, R. (2010). The phloem pathway: new issues and old debates. C. R. Biol. 333, 307-319. doi: 10.1016/j.crvi.2010.01.006

Dogimont, C., Chovelon, V., Tual, S., Boissot, N., Rittener, V., Giovinazzo, N., et al. (2008). "Molecular diversity at the Vat/Pm-W resistance locus in melon. Cucurbitaceae 2008," in Proceedings of the IXth EUCARPIA meeting on genetics and breeding of Cucurbitaceae, ed. Pitrat M (Avignon: INRA).

Dong, X., Hong, Z., Chatterjee, J., Kim, S., and Verma, D. P. (2008). Expression of callose synthase genes and its connection with Nprl signaling pathway during pathogen infection. Planta 229, 87-98. doi: 10.1007/s00425-008-0812-3

Dong, X., Hong, Z., Sivaramakrishnan, M., Mahfouz, M., and Verma, D. P. S. (2005). Callos synthase (CalS5) is required for exine formation during microgametogenesis and for pollen viability in Arabidopsis. Plant J. 42, 315328. doi: 10.1111/j.1365-313X.2005. 02379.x

Douglas, A. E. (2007). Symbiotic microorganisms: untapped resources for insect pest control. Trends Biotechnol. 25, 338-342. doi: 10.1016/j.tibtech.2007.06.003

Dugravot, S., Brunissen, L., Letocart, E., Tjallingii, W. F., Vincent, C., Giordanengo, P., et al. (2007). Local and systemic responses induced by aphids in Solanum tuberosum plants. Entomol. Exp. Appl. 123, 271277. doi: 10.1111/j.1570-7458.2007. 00542.x

Ehlers, K., Knoblauch, M., and van Bel, A. J. E. (2000). Ultrastructural features of well-preserved and injured sieve elements: minute clamps keep the phloem transport conduits free for mass flow. Protoplasma 214, 8092. doi: 10.1007/BF02524265

Enns, L. C., Kanaoka, M. M., Torii, K. U., Comai, L., Okada, K., and Cleland, R. E. (2005). Two callose synthases, GSL1 and GSL5, play an essential and redundant role in plant and pollen development and in fertility. Plant Mol. Biol. 58, 333-349. doi: 10.1007/s11103-005-4526-7

Erickson, R. H., Kim, J., Sleisenger, M. H., and Kim, Y. S. (1985). Effect of lectins on the activity of brush 
border membrane-bound enzymes of rat small intestine. J. Pediatr. Gastroenterol. Nutr. 4, 984-991. doi: 10.1097/00005176-198512000-00022

Ernst, A. M., Jekat, S. B., Zielonka, S., Müller, B., Neumann, U., Rüping, B., et al. (2012). Sieve element occlusion (SEO) genes encode structural phloem proteins involved in wound sealing of the phloem. Proc. Natl. Acad. Sci. U.S.A. 109, 1980-1989. doi: 10.1073/pnas.1202999109

Evert, R. F. (1982). Sieve-tube structure in relation to function. Bioscience 32, 789-795. doi: 10.2307/1308972

Faria, C. A., Wackers, F. L., Pritchard, J., Barrett, D. A., and Turlings, T. C. (2007). High susceptibility of $\mathrm{Bt}$ maize to aphids enhances the performance of parasitoids of lepidopteran pests. PLOS ONE 2:e600. doi: 10.1371/journal.pone.00 00600

Fitches, E., Wiles, D., Douglas, E. E., Hinchcliffe, G., Audsley, N., and Gatehouse, J. A. (2008). The insecticidal activity of recombinant garlic lectins towards aphids. Insect Biochem. Mol. Biol. 38, 905-915. doi: 10.1016/j.ibmb.2008.07.002

Froelich, D. R., Mullendore, D. L., Jensen, K. H., Ross-Elliott, T. J., Anstead, J. A., Thompson, G. A., et al. (2011). Phloem ultrastructure and pressure flow: sieve-elementocclusion-related agglomerations do not affect translocation. Plant Cell 23, 4428-4445. doi: 10.1105/tpc.111. 093179

Fromm, J., and Bauer, T. (1994). Action potentials in maize sieve tubes change phloem translocation. J. Exp. Bot. 45, 463-469. doi: 10.1093/jxb/45. 4.463

Fujita, T., Uchida, K., and Maruyama, N. (1992). Purification of senescence marker protein-30 (SMP30) and its androgen-independent decrease with age in the rat liver. Biochim. Biophys. Acta. 1116, 122 128. doi: 10.1016/0304-4165(92) 90108-7

Fukumorita, T., and Chino, M. (1982). Sugar, amino acid, and inorganic contents in rice phloem sap. Plant Cell Physiol. 23, 273-283.

Furch, A. C. U., Hafke, J. B., Schulz, A., and van Bel, A. J. E. (2007). $\mathrm{Ca}^{2+}$. mediated remote control of reversible sieve tube occlusion in Vicia faba. J. Exp. Bot. 58, 2827-2838. doi: 10.1093/jxb/erm 143

Furch, A. C. U., Hafke, J. B., and van Bel, A. J. E. (2008). Plantand stimulus-specific variations in remote-controlled sieve-tube occlusion. Plant Signal. Behav. 3, 858-861. doi: $10.4161 /$ psb.3.10.6040
Furch, A. C. U., van Bel, A. J. E. Fricker, M. D., Felle, H. H., Fuchs M., and Hafke, J. B. (2009). Sieve element $\mathrm{Ca}^{2+}$ channels as relay stations between remote stimuli and sieve tube occlusion in Vicia faba. Plant Cell 21, 2118-2132. doi: 10.1105/tpc.108.063107

Furch, A. C. U., Zimmermann, M. R., Will, T., Hafke, J. B., and van Bel, A. J. E. (2010). Remote-controlled stop of phloem mass flow by biphasic occlusion in Cucurbita maxima. J. Exp. Bot. 61, 3697-3708. doi: 10.1093/jxb/erq181

Gattolin, S., Newbury, H. J., Bale, J. S., Tseng, H.-M., Barrett, D. A., and Pritchard, J. (2008). A diurnal component to the variation in sieve tube amino acid content in wheat. Plant Physiol. 147, 912-921. doi: 10.1104/pp.108. 116079

Giordanengo, P., Brunissen, L., Rusterucci, C., Vincent, C., van Bel, A. J. E., Dinant, S., et al. (2010). Compatible plant-aphid interactions: how aphids manipulate plant responses. C. R. Biol. 333, 516-523. doi: 10.1016/j.crvi.2010.03.007

Girousse, C., Bonnemain, J.-L., Delrot, S., and Bournoville, R. (1991). Sugar and amino acid composition of phloem sap of Medicago sativa: a comparative study of two collecting methods. Plant Physiol. Biochem. 29, 41-48.

Girousse, C., Bournoville, R., and Bonnemain, J.-L. (1996). Water deficitinduced changes in concentrations in proline and some other amino acids in the phloem sap of Alfalfa. Plant Physiol. 111, 109-113.

Gould, N., Minchin, P. E. H., and Thorpe, M. R. (2004). Direct measurements of sieve element hydrostatic pressure reveal strong regulation after pathway blockage. Funct. Plant Biol. 31, 987-993. doi: 10.1071/FP04058

Gould, N., Thorpe, M. R., Koroleva, O., and Minchin, P. E. H. (2005). Phloem hydrostatic pressure relates to solute loading rate: a direct test of the Münch hypothesis. Funct. Plant Biol. 32, 1019-1026. doi: 10.1071/ FP05036

Gündüz, E. A., and Douglas, A. E. (2009). Symbiotic bacteria enable insect to utilize a nutritionallyinadequate diet. Proc. R. Soc. Lond. $B$ Biol. Sci. 276, 987-991. doi: 10.1098/rspb.2008.1476

Günthardt, M. S., and Wanner, H. (1981). The feeding behaviour of two leafhoppers on Vicia faba. Ecol. Entomol. 6, 17-22. doi: 10.1111/j.13652311.1981.tb00968.x
Guseman, J. M., Lee, J. S., Bogenschutz, N. L., Peterson, K. M., Virata, R. E. Xie, B., et al. (2010). Dysregulation of cell-to-cell connectivity and stomatal patterning by loss-of-function mutation in Arabidopsis chorus (glucan synthase-like 8). Development 137 , 1731-1741. doi: 10.1242/dev.049197

Hafke, J. B., Furch, A. C. U., Fricker, M. D., and van Bel, A. J. E. (2009). Forisome dispersion in Vicia faba is triggered by $\mathrm{Ca}^{2+}$ hotspots created by concerted action of diverse $\mathrm{Ca}^{2+}$ channels in sieve elements. Plant Signal. Behav. 4, 968-972. doi: 10.4161/psb.4.10.9671

Hafke, J. B., van Amerongen, J.-K., Kelling, F., Furch, A. C. U., Gaupels, F., and van Bel, A. J. E. (2005). Thermodynamic battle for photosynthate acquisition between sieve tubes and adjoining parenchyma in transport phloem. Plant Physiol. 138, 1527-1537. doi: 10.1104/pp.104. 058511

Hammel, H. T. (1968). Measurement of turgor pressure and its gradient in the phloem of oak. Plant Physiol. 43, 1042-1048. doi: 10.1104/pp.43.7.1042

Hao, P., Liu, C., Wang, Y., Chen, R., Tang, M., Du, B., et al. (2008) Herbivore-induced callose deposition on the sieve plates of rice: an important mechanism for host resistance. Plant Physiol. 146, 1810-1820. doi: 10.1104/pp.107.111484

Haritatos, E., Keller, F., and Turgeon, R. (1996). Raffinose oligosaccharide concentrations measured in individual cell and tissue types in Cucumis melo L. leaves: implications for phloem loading. Planta 198, 614622. doi: 10.1007/BF00262649

Harmel, N., Letocart, E., Cherqui, A., Giordanengo, P., Mazzuchelli, G., Guillonneau, P., et al. (2008). Identification of aphid salivary proteins: a proteomic investigation of Myzus persicae. Insect Mol. Biol. 17, 165-174. doi: 10.1111/j.13652583.2008.00790.x

Harris, K. F., Treur, B., Tsai, J., and Toler, R. (1981). Observations on leafhopper ingestion-egestion behavior: its likely role in the transmission of non-circulative viruses and other plant pathogens. J. Econ. Entomol. 74, 446-453.

Hattori, M., Nakamura, M., Komatsu, S., Tsuchihara, K., Tamura, Y., and Hasegawa, T. (2012). Molecular cloning of a novel calciumbinding protein in the secreted saliva of the green rice leafhopper Nephotettix cincticeps. Insect Biochem. Mol. Biol. 42:1-9. doi: 10.1016/j.ibmb.2011.10.001
Hayashi, H., and Chino, M. (1986). Collection of pure phloem sap from wheat and its chemical composition. Plant Cell Physiol. 27, 1387-1393.

Hayashi, H., and Chino, M. (1990). Chemical composition of phloem sap from the uppermost internode of the rice plant. Plant Cell Physiol. 31, 247-251.

Hewer, A., Becker, A., and van Bel, A. J. E. (2011). An aphid's Odyssey - the cortical quest for the vascular bundle. J. Exp. Biol. 214, 3868-3879. doi: 10.1242/jeb.060913

Hewer, A., Will, T., and van Bel, A. J. E. (2010). Plant cues for aphid navigation in vascular tissues. $J$. Exp. Biol. 213, 4030-4042. doi: 10.1242/jeb.046326

Hilder, V. A., Powell, K. S., Gatehouse, A. M. R., Gatehouse, J. A., Gatehouse, L. N., Shi, Y., et al. (1995). Expression of snowdrop lectin in transgenic tobacco plants results in added protection against aphids. Transgenic Res. 4, 18-25. doi: 10.1007/BF01976497

Hogenhout, S. A., and Bos, J. I. B. (2011). Effector proteins that modulate plant-insect interactions. Curr. Opin. Plant Biol. 14, 1-7. doi: 10.1016/j.pbi.2011.05.003

Hogenhout, S. A., van der Hoorn, R. A. L., Terauchi, R., and Kamoun, S. (2009). Emerging concepts in effector biology of plant-associated organisms. Mol. Plant Microbe Interact. 22, 115-122. doi: 10.1094/MPMI-22-20115

Hong, Z., Delauney, A. J., and Verma, D. P. S. (2001). A cell-plate specific callose synthase and its interaction with phragmoplastin. Plant Cell 13, 755-768. doi: 10.1105/tpc.13.4.755

Huang, L., Chen, X.-Y., Rim, Y., Han, X., Cho, W. K., Kim, S.-W., et al. (2009). Arabidopsis glucan synthase-like 10 functions in male gametogenesis. J. Plant Physiol. 166, 344-352. doi: 10.1016/j.jplph.2008.06.010

IAGC. (2010). Genome sequence of the pea aphid Acyrthosiphon pisum. PLoS Biol. 8:e1000313. doi: 10.1371/journal.pbio.1000313

Jacobs, K., Lipka, V., Burton, R. A., Panstruga, R., Strizhov, N., Paul Schulze-Lefert, P., et al. (2003). An Arabidopsis callose synthase, GSL5, is required for wound and papillary callose formation. Plant Cell 15, 2503-2513. doi: 10.1105/tpc.016097

Kauss, H. (1987). Some aspects of calcium-dependent regulation in plant metabolism. Annu. Rev. Plant Physiol. 38, 47-72. doi: $10.1146 /$ annurev.pp.38.06018 7.000403

Kempers, R., Ammerlaan, A., and van Bel, A. J. E. (1998). Symplasmic 
constriction and ultrastructural features of the sieve element/companion cell complex in the transport phloem of apoplasmically and symplasmically phloem-loading species. Plant Physiol. 116, 271-278. doi: 10.1104/pp.116.1.271

Kleinig, H. (1975). Filament formation in vitro of a sieve tube protein from Cucurbita maxima and Cucurbita pepo. Planta 127, 163-170. doi: 10.1007/BF00388377

Knoblauch, M., Noll, G., Müller, T., Prüfer, D., Schneider-Hüther, I., Scharner, D., et al. (2003). ATP-independent contractile proteins from plants. Nat. Mater. 2, 600-604. doi: 10.1038/nmat960

Knoblauch, M., Noll, G., Müller, T., Prüfer, D., Schneider-Hüther, I., Scharner, D., et al. (2005). Corrigendum: ATP-independent contractile proteins from plants. Nat. Mater. 4, 353. doi: 10.1038/nmat1355a

Knoblauch, M., Peters, W. S., Ehlers, K., and van Bel, A. J. E. (2001). Reversible calcium-regulated stopcocks in legume sieve tubes. Plant Cell 13, 1221-1230. doi: 10.1105/tpc.13.5.1221

Knoblauch, M., Stubenrauch, M., van Bel, A. J. E., and Peters, W. S. (2012). Forisome performance in artificial sieve tubes. Plant Cell Environ. 35, 1419-1427. doi: 10.1111/j.13653040.2012.02499.x

Knoblauch, M., and van Bel, A. J. E. (1998). Sieve tubes in action. Plant Cell 10, 35-50. doi: 10.1105/tpc.10.1.35

Kudlicka, K., and Brown, R. M. (1997). Cellulose and callose biosynthesis in higher plants. Plant Physiol. 115, 643-656. doi: 10.1104/pp.115.2.643

Kusnierczyk, A., Tran, D. H. T., Winge, P., Jørstad, T. S., Reese, J. C., Troczynska, J., etal. (2011). Testing the importance of jasmonate signalling in induction of plant defences upon cabbage aphid (Brevicoryne brassicae) attack. BMC Genomics 12:423. doi: 10.1186/1471-2164-12-423

Lecourieux, D., Ranjeva, R., and Pugin, A. (2006). Calcium in plantsignalling pathways. New Phytol. 171, 249-269. doi: 10.1111/j.14698137.2006.01777.x

Le-Feuvre, R. R., Ramirez, C. C., Olea, N., and Meza-Basso, L. (2007). Effect of the antimicrobial peptide indolicidin on the green peach aphid Myzus persicae (Sulzer). J. Appl. Entomol. 131, 71-75. doi: 10.1111/j.14390418.2006.01117.x

Leineweber, K., Schulz, A., and Thompson, G. A. (2000). Dynamic transitions in the translocated phloem filament protein. Aust. J. Plant
Physiol. 27, 733-741. doi: 10.1071/ PP99161

Leubner-Metzger, G. (2003). Functions and regulation of beta-1,3-glucanases during seed germination, dormancy release and after-ripening. Seed Sci. Res. 13, 17-34. doi: 10.1079/SSR2002121

Levy, A., Erlanger, M., Rosenthal, M., and Epel, B. L. (2007). A plasmodesmata-associated $\beta-1,3-$ glucanase in Arabidopsis. Plant $J$. 49, 669-682. doi: 10.1111/j.1365313X.2006.02986.x

Lohaus, G., Büker, M., Hußmann, M., Soave, C., and Heldt, H.-W. (1998). Transport of amino acids with special emphasis on the synthesis and transport of asparagine in the Illinois low protein and Illinois high protein strains of maize. Planta 205, 181-188. doi: 10.1007/s004250 050310

Lohaus, G., and Moellers, C. (2000). Phloem transport of amino acids in two Brassica napus L. genotypes and one $B$. carinata genotype in relation to their seed protein content. Planta 211, 833-840. doi: $10.1007 / \mathrm{s} 004250000349$

Louis, J., and Shah J. (2013). Arabidopsis thaliana-Myzus persicae interaction: shaping the understanding of plant defense against phloem-feeding aphids. Front. Plant Sci. 4:213. doi: 10.3389/fpls.2013.00213

Louis, J., Singh, V., and Shah, J. (2012). Arabidopsis thaliana - aphid interaction. Arabidopsis Book 10:e0159. doi: 10.1199/tab.0159

Lukasik, P., van Asch, M., Guo, H., Ferrari, J., Charles, H., and Godfray, J. (2012). Unrelated facultative endosymbionts protect aphids against a fungal pathogen. Ecol. Lett. 16, 214-218. doi: 10.1111/ele. 12031

Ma, R., Reese, J. C., Black, W. C. IV, and Bramel-Cox, P. (1990). Detection of pectinesterase and polygalacturonase from salivary secretions of living greenbugs, Schizaphis graminum (Homoptera: Aphididae). J. Insect Physiol. 36, 507512. doi: 10.1016/0022-1910(90) 90102-L

Madhusudhan, V. V., and Miles, P. W. (1998). Mobility of salivary components as a possible reason for differences in the responses of alfalfa to the spotted alfalfa aphid and pea aphid. Entomol. Exp. Appl. 86, 2539. doi: 10.1046/j.1570-7458.1998. 00262.x

Martens, H. J., Roberts, A. G., Oparka, K. J., and Schulz, A. (2006). Quantification of plasmodesmatal endoplasmic reticulum coupling between sieve elements and companion cells using fluorescence redistribution after photobleaching. Plant Physiol. 142, 471-480. doi: 10.1104/pp.106. 085803

Martin, B., Collar, J. L., Tjallingii, W. F., and Fereres, A. (1997). Intracellular ingestion and salivation by aphids may cause the acquisition and inoculation of non-persistently transmitted plant viruses. J. Gen. Virol. 78, 2701-2705.

Martinez de Ilarduya, O., Xie, Q.-G., and Kaloshian, I. (2003). Aphidinduced defense responses in $\mathrm{Mi}$ 1-mediated compatible and incompatible tomato interactions. Mol. Plant Microbe Interact. 16, 699708. doi: 10.1094/MPMI.2003.16. 8.699

McLean, D. L., and Kinsey, M. G. (1965). Identification of electrically recorded curve patterns associated with aphid salivation and ingestion. Nature 205, 1130-1131. doi: 10.1038/2051 $130 \mathrm{a} 0$

Miles, P. W. (1965). Studies on the salivary physiology of plant-bugs: the salivary secretions of aphids. $J$. Insect Physiol. 11, 1261-1268. doi: 10.1016/0022-1910(65)90119-8

Miles, P. W. (1999). Aphid saliva. Biol. Rev. Camb. Philos. Soc. 74, 41-85. doi: 10.1017/S0006323198005271

Moreno, A., Garzo, E., FernandezMata, G., Kassem, M., Aranda, M. A., and Fereres, A. (2011). Aphids secrete watery saliva into plant tissues from the onset of stylet penetration. Entomol. Exp. Appl. 139, 145-153. doi: 10.1111/j.1570-7458. 2011.01117.x

Morgan, J. K., Luzio, G. A., Ammar, E.-D., Hunter, W. B., Hall, D. G., and Shatters, R. G. Jr. (2013). Formation of stylet sheaths in aere (in air) from eight species of phytophagous hemipterans from six families (suborders: Auchenorrhyncha and Sternorrhyncha). PLOS ONE 8:e62444. doi: 10.1371/journal.pone. 0062444

Mullendore, D. L., Windt, C. W. Henk Van, A., and Knoblauch, M. (2010). Sieve tube geometry in relation to phloem flow. Plant Cell 22, 579-593. doi: 10.1105/tpc.109. 070094

Münch, E. (1930). Die Stoffbewegung in der Pflanze. Jena: Fischer.

Mutti, N. S., Louis, J., Pappan, L. K., Pappan, K., Begum, K., Chen, M. S., et al. (2008). A protein from the salivary glands of the pea aphid, Acyrthosiphon pisum, is essential in feeding on a host plant. Proc. Natl. Acad. Sci. U.S A.
105, 9965-9969. doi: 10.1073/pnas. 0708958105

Mutti, N. S., Park, Y., Reese, J. C., and Reeck, G. R. (2006). RNAi knockdown of a salivary transcript leading to lethality in the pea aphid, Acyrthosiphon pisum. J. Insect Sci. 6, 38. doi: 10.1673/031.006.3801

Nadwodnik, J., and Lohaus, G. (2008). Subcellular concentrations of sugar alcohols and sugars in relation to phloem translocation in Plantago major, Plantago maritima, Prunus persica, and Apium graveolens. Planta 227, 1079-1089. doi: 10.1007/s00425-007-0682-0

Nakashima, J., Laosinchai, W., Cui, X., and Brown, R. M. Jr. (2003). New insight into the mechanism of cellulose and callose biosynthesis: proteases may regulate callose biosynthesis upon wounding. Cellulose 10, 369-389. doi: 10.1023/A:1027336605479

Nicholson, S. J., Hartson, S. D., and Puterka, G. J. (2012). Proteomic analysis of secreted saliva from Russian Wheat Aphid (Diuraphis noxia Kurd.) biotypes that differ in virulence to wheat. J. Proteomics 75, 2252-2268. doi: 10.1016/j.jprot.2012. 01.031

Nishikawa, S., Zinkl, G. M., Swanson, R. J., Maruyama, D., and Preuss, D. (2005). Callose ( $\beta-1,3$ glucan) is essential for Arabidopsis pollen wall patterning, but not tube growth. BMC Plant Biol. 5:22. doi: 10.1186/1471-2229-5-22

Nishimura, M. T., Stein, M., Hou, B. H., Vogel, J. P., Edwards, H., and Somerville, S. C. (2003). Loss of a callose synthase results in salicylic acid-dependent disease resistance. Science 301, 969-972. doi: 10.1126/science. 1086716

Noll, G. A. (2005). Molekularbiologische Charakterisierung der Forisome. Doctoral thesis, Justus-Liebig Universität, Gießen.

Noll, G. A., Fontanellaz, M. E., Rüping, B., Ashoub, A., van Bel, A. J. E., Fischer, R., et al. (2007). Spatial and temporal regulation of the forisome gene for 1 in the phloem during plant development. Plant Mol. Biol. 65, 285-294. doi: 10.1007/s11103-0079217-0

Ohshima, T., Hayashi, H., and Chino, M. (1990). Collection and chemical composition of pure phloem sap from Zea mays L. Plant Cell Physiol. 31, 735-737.

Palevitz, B. A., and Newcomb, E. H. (1971). The ultrastructure and development of tubular and crystalline $\mathrm{P}$ protein in the sieve elements of certain papilionaceous 
legumes. Protoplasma 72, 399-426. doi: 10.1007/BF01289511

Pélissier, H. C., Peters, W. S., Collier, R., van Bel, A. J. E., and Knoblauch, M. (2008). GFP tagging of sieve element occlusion (SEO) proteins results in green fluorescent forisomes. Plant Cell Physiol. 49, 1699-1710. doi: $10.1093 / \mathrm{pcp} / \mathrm{pcn} 141$

Pescod, K. V., Quick, W. P., and Douglas, A. E. (2007). Aphid responses to plants with genetically manipulated phloem nutrient levels. Physiol. Entomol. 32, 253-258. doi: 10.1111/j.1365-3032. 2007.00577.x

Peters, W. S., Knoblauch, M., Warmann, S. A., Pickard, W. F., and Shen, A. Q. (2008). Anisotropic contraction in forisomes: simple models won't fit. Cell Motil. Cytoskeleton 65, 368-378. doi: $10.1002 / \mathrm{cm} .20266$

Peters, W. S., Knoblauch, M., Warmann, S. A., Schnetter, R., Shen, A. Q., and Pickard, W. F. (2007). Tailed forisomes of Canavalia gladiate: a new model to study $\mathrm{Ca}^{2+}$. driven protein contractility. Ann. Bot. 100, 101-109. doi: 10.1093/aob/ $\mathrm{mcm} 080$

Pieterse, C. M. J., van der Does, D., Zamioudis, C., Leon-Reyes, A., and van Wees, S. C. M. (2012). Hormonal modulation of plant immunity. Annu. Rev. Cell Dev. Biol. 28, 489-521. doi: 10.1146/annurevcellbio-092910-154055

Pitino, M., Coleman, A. D., Maffei, M. E., Ridout, C. J., and Hogenhout, S. A. (2011). Silencing of aphid genes by dsRNA feeding from plants. PLoS ONE 6:e25709. doi: 10.1371/journal.pone.0025709

Pitino, M., and Hogenhout, S. A. (2013). Aphid protein effectors promote aphid colonization in a plant species-specific manner. Mol. Plant Microbe Interact. 26, 130 139. doi: 10.1094/MPMI-07-120172-FI

Pollard, D. G. (1973). Plant penetration by feeding aphids (Hemiptera: Aphidoidea): a review. Bull. Entomol. Res. 62, 631-714. doi: 10.1017/S0007485 300005526

Prado, E., and Tjallingii, W. F. (1994) Aphid activities during sieve element punctures. Entomol. Exp. Appl. 72, 157-165. doi: 10.1111/j.15707458.1994.tb01813.x

Pyati, P., Bandani, A. R., Fitches, E., and Gatehouse, J. A. (2011). Protein digestion in cereal aphids (Sitobion avenae) as a target for plant defence by endogenous proteinase inhibitors. J. Insect Physiol. 57, 881891. doi: 10.1016/j.jinsphys.2011. 03.024
Rahbé, Y., Deraison, C., BonadéBottino, M., Girard, C., Nardon, C., and Jouanin, L. (2003). Effects of the cysteine protease inhibitor oryzacystatin (OC-I) of different aphids and reduced performance of Myzus persicae on OC-I expressing transgenic oilseed rape. Plant Sci. 164, 441450. doi: 10.1016/S0168-9452(02) 00402-8

Rahbé, Y., Sauvion, N., Febvay, G., Peumans, W. J., and Gatehouse, A. M. R. (1995). Toxicity of lectins and processing of ingested proteins in the pea aphid Acyrthosiphon pisum. Entomol. Exp. Appl. 76, 143155. doi: 10.1111/j.1570-7458.1995. tb01956.x

Rao, S. A., Carolan, J. C., and Wilkinson, T. L. (2013). Proteomic profiling of cereal aphid saliva reveals both ubiquitous and adaptive secreted proteins. PLoS ONE 8:e57413. doi: 10.1371/journal. pone. 0057413

Read, S. M., and Northcote, D. H. (1983). Chemical and immunological similarities between the phloem proteins of three genera of the Cucurbitaceae. Planta 158, 119-127. doi: 10.1007/BF00397704

Ribeiro, A. P. O., Pereira, E. J. G., Galvan, T. L., Picanco, M. C., Picoli, E. A. T., da Silva, D. J. H., et al. (2006). Effect of eggplant transformed with oryzacystatin gene on Myzus persicae and Macrosiphum euphorbiae. J. Appl. Entomol. 130, 8490. doi: $10.1111 /$ j.1439-0418.2005. 01021.x

Rodriguez-Medina, C. (2009). Study of Macromolecules in Phloem Exudates of Lupinus albus. Ph.D. dissertation, School of Plant Biology, University of Western Australia, Crawley.

Rogers, S., and Peel, A. J. (1975). Some evidence for the existence of turgor pressure gradients in the sieve tubes of willow. Planta 126, 259-267. doi: 10.1007/BF00388967

Rüping, B., Ernst, A. M., Jekat, S. B., Nordzieke, S., Reineke, A. R., Müller, B., etal. (2010). Molecular and phylogenetic characterization of the sieve element occlusion gene family in Fabaceae and nonFabaceae plants. BMC Plant Biol. 10:219. doi: 10.1186/1471-222910-219

Russell, J. A., and Moran, N. A. (2006). Costs and benefits of symbiont infection in aphids: variation among symbionts and across temperatures. Proc R. Soc. Lond. B Biol. Sci. 273, 603-610. doi: $10.1098 /$ rspb. 2005.3348

Sauvion, N., Nardon, C., Febvay, G., Gatehouse, A. M., and Rahbé, Y. (2004). Binding of the insecticidal lectin Concanavalin A in pea aphid, Acyrthosiphon pisum (Harris) and induced effects on the structure of midgut epithelial cells. J. Insect Physiol. 50, 1137 1150. doi: 10.1016/j.jinsphys.2004. 10.006

Sauvion, N., Rahbé, Y., Peumans, W. J., van Damme, E. J. M., Gatehouse, J. A., and Gatehouse, A. M. R. (1996). Effects of GNA and other mannose binding lectins on development and fecundity of the peach-potato aphid Myzus persicae. Entomol. Exp. Appl. 79, 285-293. doi: 10.1111/j.15707458.1996.tb00836.x

Schobert, C., Baker, L., Szederkényi, J., Großmann, P., Komor, E., Hayashi, H., et al. (1998). Identification of immunologically related proteins in sieve-tube exudate collected from monocotyledonous and dicotyledonous plants. Planta 206, 245-252. doi: $10.1007 / \mathrm{s} 004250050396$

Schulz, A. (1998). The phloem. Structure related to function. Prog. Bot. 59, 429-475. doi: 10.1007/978-3-64280446-5_16

Shimada, H., Koishihara, H., Saito, Y., Arashima, Y., Furukawa, T., and Hayashi, H. (2004). A rice antisense SPK transformant that lacks the accumulation of seed storage substances shows no correlation between sucrose concentration in phloem sap and demand for carbon sources in the sink organs. Plant Cell Physiol. 45, 1105-1109. doi: $10.1093 / \mathrm{pcp} /$ pch122

Shimokawa, N., and Yamaguchi, M. (1993). Expression of hepatic calcium-binding protein regucalcin mRNA is mediated through $\mathrm{Ca}^{2+} /$ calmodulin in rat liver. FEBS Lett. 316, 79-84. doi: 10.1016/00145793(93)81740-Q

Sjölund, R. D. (1997). The phloem sieve element: a river runs through it. Plant Cell 9, 1137-1146. doi: 10.1105/tpc.9.7.1137

Smith, C. M., and Clement, S. L. (2012). Molecular bases of plant resistance to arthropods. Ann. Rev. Entomol. 57, 309-328. doi: 10.1146/annurev-ento120710-100642

Steer, M. W., and Newcomb, E. H. (1969). Development and dispersal of P-protein in the phloem of Coleus blumei Benth. J. Cell Sci. 4, 155-169.

Stergiopoulos, I., and de Wit, P. J. G. M. (2009). Fungal effector proteins. Annu. Rev. Phytopathol. 47, 233263. doi: 10.1146/annurev.phyto.11 2408.132637

Takemoto, H., Uefune, M., Ozawa, R., Arimura, G. I., and Takabayashi, J. (2013). Previous infestation of pea aphids Acyrthosiphon pisum on broad bean plants resulted in the increased performance of conspecific nymphs on the plants. J. Plant Interact. doi: 10.1080/17429145.2013. 786792

Thiele, K., Wanner, G., Kindzierski, V., Jürgens, G., Mayer, U., Pachl, F., et al. (2008). The timely deposition of callose is essential for cytokinesis in Arabidopsis. Plant J. 58, 1326. doi: 10.1111/j.1365-313X.2008. 03760.x

Thorpe, M. R., Furch, A. C. U., Minchin, P. E. H., Föller, J., van Bel, A. J. E., and Hafke, J. B. (2010). Rapid cooling triggers forisome dispersion just before phloem transport stops. Plant Cell Environ. 33, 259-271. doi: 10.1111/j.1365-3040.2009.02079.x

Tjallingii, W. F. (2006). Salivary secretions by aphids interacting with proteins of phloem wound responses. J. Exp. Bot. 57, 739-745. doi: 10.1093/jxb/erj088

Tjallingii, W. F., and Esch, T. H. (1993). Fine structure of aphid stylet routes in plant tissues in correlation with EPG signals. Physiol. Entomol. 18, 317-328. doi: 10.1111/j.13653032.1993.tb00604.x

Töller, A., Brownfield, L., Neu, C., Twell, D., and Schulze-Lefert, P. (2008). Dual function of Arabidopsis glucan synthase-like genes GSL8 and GSL10 in male gametophyte development and plant growth. Plant J. 54, 911-923. doi: 10.1111/j.1365313X.2008.03462.x

Trewavas, A. (1999). Le calcium, c'est la vie: calcium makes waves. Plant Physiol. 120, 1-6. doi: 10.1104/pp.120.1.1

Turgeon, R., and Wolf, S. (2009). Phloem transport: cellular pathways and molecular trafficking. Annu. Rev. Plant Biol. 60, 207221. doi: 10.1146/annurev.arplant. 043008.092045

Tuteja, N., Umate, P., and van Bel, A. J. E. (2010). Forisomes: calcium-powered protein complexes with potential as "smart" biomaterials. Trends Biotech. 28, 102-110. doi: 10.1016/j.tibtech.2009.11.005

Urbanska, A., Tjallingii, W. F., Dixon, A. F. G., and Leszczynski, B. (1998). Phenol oxidizing enzymes in the grain aphid's saliva. Entomol. Exp. Appl. 86, 197-203. doi: 10.1046/j.15707458.1998.00281.x

Uzest, M., Gargani, D., Dombrovsky, A., Cazevieille, C., Cot, D., and Blanc, S. (2010). The "acrostyle": a newly described anatomical structure in aphid stylets. Arthropod Struct. Dev. 39, 221-229. doi: 10.1016/j.asd.2010.02.005

van Bel, A. J. E. (1996). Interaction between sieve element and 
companion cell and the consequence for photoassimilate distribution: two structural hardware frames with associated physiological software packages in dicotyledons. $J$. Exp. Bot. 47, 1129-1140. doi: 10.1093/jxb/47.Special_Issue.1129

van Bel, A. J. E. (2003). The phloem, a miracle of ingenuity. Plant Cell Environ. 26, 125-149. doi: 10.1046/j.1365-3040.2003.00963.x

van Bel, A. J. E., and Gaupels, F. (2004). Pathogen-induced resistance and alarm signals in the phloem. Mol. Plant Pathol. 5, 465504. doi: 10.1111/j.1364-3703.2004. 00243.x

van Bel, A. J. E., and Knoblauch, M. (2000). Sieve element and companion cell: the story of the comatose patient and the hyperactive nurse. Aust. J. Plant Physiol. 27, 477-487. doi: 10.1071/PP99172

Voitsekhovskaja, O. V., Koroleva, O. A., Batashev, D. R., Knop, C., Tomos, A. D., Gamalei, Y. V., et al. (2006). Phloem loading in two Scrophulariaceae species. What can drive symplastic flow via plasmodesmata? Plant Physiol.140, 383-395. doi: 10.1104/pp.105.068312

Walker, G. P., and Medina-Ortega, K. J. (2012). Penetration of faba bean sieve elements by pea aphid does not trigger forisome dispersal. Entomol. Exp. Appl. 144, 326-335. doi: 10.1111/j.1570-7458.2012.01297.x

Walling, L. L. (2008). Avoiding effective defenses: strategies employed by phloem-feeding insects. Plant Physiol. 146, 859-866. doi: 10.1104/pp.107.113142

Wang, N., and Nobel, P. S. (1995). Phloem exudate collected via scale insect stylets for the CAM Species Opuntia ficus-indica under current and doubled $\mathrm{CO} 2$ concentrations. Ann. Bot. 75, 525-532. doi: 10.1006/anbo.1995.1054

Wang, Y., Tang, M., Hao, P. Y., Yang, Z. F., Zhu, L. L., and He, G. C. (2008). Penetration into rice tissues by brown planthopper and fine structure of the salivary sheaths. Entomol. Exp. Appl. 129, 295-307. doi: 10.1111/j.1570-7458.2008.00785.x

Wensler, R. J., and Filshie, B. K. (1969). Gustatory sense organs in the food channel of aphids. J. Morphol. 129, 473-492. doi: 10.1002/jmor.1051290406

Will, T., Steckbauer, K., Hardt, M., and van Bel, A. J. E. (2012a). Aphid gel saliva: sheath structure, protein composition, and secretors dependence on stylet-tip milieu. PLoS ONE 7:e46903. doi: 10.1371/journal.pone.0046903

Will, T., Carolan, J. C., and Wilkinson, T. L. (2012b). "Breaching the sieve element: the role of saliva as the molecular interface between aphids and the phloem," in Biochemistry of Phloem eds G. A. Thompson and A. J. E. van Bel (Hoboken: Wiley-Blackwell), 310-327.

Will, T., Hewer, A., and van Bel, A. J. E. (2008). A novel perfusion system shows that aphid feeding behaviour is altered by decrease of sieve-tube pressure. Entomol. Exp. Appl. 127, 237245. doi: $10.1111 / \mathrm{j} .1570-7458.2008$. 00687.x

Will, T., Kornemann, S. R., Furch, A. C. U., Tjallingii, W. F., and van Bel, A. J. E. (2009). Aphid watery saliva counteracts sieve-tube occlusion: a universal phenomenon? J. Exp. Biol. 212, 3305-3312. doi: 10.1242/jeb. 028514

Will, T., Tjallingii, W. F., Thönnessen, A., and van Bel, A. J. E. (2007) Molecular sabotage of plant defense by aphid saliva. Proc. Natl. Acad. Sci. U.S.A.104, 10536-10541. doi: 10.1073/pnas.0703535104

Will, T., and van Bel, A. J. E. (2006). Physical and chemical interactions between aphids and plants. J. Exp. Bot. 57, 729-737. doi: 10.1093/jxb/erj089

Will, T., and van Bel, A. J. E. (2008) Induction as well as suppression: how aphid saliva may exert opposite effects on plant defense. Plant Signal. Behav. 3, 427-430. doi: 10.4161/psb.3.6.5473

Will, T., and Vilcinskas, A. (2013). "Aphid proofed plants: biotechnical approaches for aphid control," in Advances in Biochemical Engineering/Biotechnology - Yellow Biotechnology, ed. A. Vilcinskas (Heidelberg: Springer). doi: 10.1007/10_2013_211 [Epub ahead of print].
Wright, J. P., and Fisher, D. B. (1980) Direct measurement of sieve tube turgor pressure using severed aphid stylets. Plant Physiol. 65, 1133-1135. doi: 10.1104/pp.65.6.1133

Xie, B., Wang, X., and Hong, Z. (2010). Precocious pollen germination in Arabidopsis plants with altered callose deposition during microsporogenesis. Planta 231, 809-823. doi: 10.1007/s00425-0091091-3

Xie, B., Wang, X., Zhu, M., Zhang, Z., and Hong, Z. (2011). CalS7 encodes a callose synthase responsible for callose deposition in the phloem. Plant J. 65, 1-14. doi: 10.1111/j.1365313X.2010.04399.x

Yamaguchi, M. (2000). Role of regucalcin in calcium signaling. Life Sci. 66, 1769-1780. doi: 10.1016/S0024 3205(99)00602-5

Yamaguchi, M. (2005). Role of regucalcin in maintaining cell homeostasis and function. Int. J. Mol. Med. 15 371-389.

Zabotin, A. I., Barysheva, T. S., Trofimova, O. I., Lozovaya, V. V., and Widholm, J. (2002). Regulation of callose metabolism in higher plant cells in vitro. Russ. J. Plant Physiol. 49 792-798. doi: 10.1023/A:10209697 30151

Zarate, S. I., Kempema, L. A., and Walling, L. L. (2007). Silverleaf whitefly salicylic acid defense and suppresses effectual jasmonic acid defense. Plant Physiol. 143, 866-875. doi: 10.1104/pp.106.090035

Zhang, B., Tolstikov, V., Turnbull, C., Hicks, L. M., and Fiehn, O. (2010). Divergent metabolome and proteome suggest functional independence of dual phloem transport systems in cucurbits. Proc. Natl. Acad. Sci. U.S.A. 107, 13532-13537. doi: 10.1073/pnas.0910558107

Zhang, C., Shi, H., Chen, L. Wang, X., Lü, B., Zhang, S., et al. (2011). Harpin-induced expression and transgenic over expression of the phloem protein gene AtPP2-A1 in Arabidopsis repress phloem feeding of the green peach aphid Myzus persicae. BMC Plant Biol. 11:11. doi: 10.1186/1471-2229-11-11

Zhu-Salzman, K., Salzman, R. A., Ahn, J.-E., and Koiwa, H. (2004)
Transcriptional regulation of Sorghum defense determinants against phloem-feeding aphid. Plant Physiol. 134, 420-431. doi: 10.1104/pp.103.028324

Zimmermann, M. R., Hafke, J. B., van Bel, A. J. E., and Furch, A. C. U. (2013). Interaction of xylem and phloem during exudation and wound occlusion in Cucurbita maxima. Plant Cell Environ. 36, 237247. doi: 10.1111/j.1365-3040.2012. 02571.x

Zimmermann, M. R., and Mithöfer, A. (2013). "Electrical long distance signaling in plants," in LongDistance Systemic Signaling and Communication in Plants, ed. F. Baluska (Heidelberg: Springer), 291308. doi: 10.1007/978-3-642-3647 0-9_15

Zipfel, C. (2008). Pattern-recognition receptors in plant innate immunity. Curr. Opin. Immunol. 20, 10-16. doi: 10.1016/j.coi.2007.11.003

Conflict of Interest Statement: The authors declare that the research was conducted in the absence of any commercial or financial relationships that could be construed as a potential conflict of interest.

Received: 25 March 2013; accepted: 09 August 2013; published online: 29 August 2013.

Citation: Will T, Furch ACU and Zimmermann MR (2013) How phloemfeeding insects face the challenge of phloem-located defenses. Front. Plant Sci. 4:336. doi: 10.3389/fpls.2013.00336 This article was submitted to Plant Physiology, a section of the journal Frontiers in Plant Science.

Copyright (C) 2013 Will, Furch and Zimmermann. This is an open-access article distributed under the terms of the Creative Commons Attribution License (CC BY). The use, distribution or reproduction in other forums is permitted, provided the original author(s) or licensor are credited and that the original publication in this journal is cited, in accordance with accepted academic practice. No use, distribution or reproduction is permitted which does not comply with these terms. 